\title{
Eksperimen Pengembangan Ragam Hias Keramik di Usaha Tembikar Lestari Deli Serdang
}

\section{Experiments on the Development of Decorative Ceramics in Deli Serdang's Lestari Pottery Business}

\author{
Sartika Sinaga*, Heri Soeprayogi \& Mesra \\ Program Studi Pendidikan Seni Rupa, Jurusan Seni Rupa, Fakultas Bahasa Dan Seni, \\ Universitas Negeri Medan, Indonesia
}

Diterima: 01 Oktober 2020; Direview : 10 Oktober 2020; Disetujui: 17 Oktober 2020

Email:sartikayani04@gmail.com

\begin{abstract}
Abstrak
Penelitian ini bertujuan untuk menngembangkan ragam hias pada produk keramik di usaha kerajinan Tembikar Lestari yang ditinjau dari indikator prinsip-prinsip kerajinan, yang dilaksanakan di Usaha Tembikar Lestari di Jalan Medan Tanjung Morawa, Km 13 No. 27 di Desa Bangun Sari Kecamatan Tanjung Morawa Kabupaten Deli Serdang. Penelitian ini merupakan penelitian yang menggunakan metode pengembangan dan eksperimen. Sampel untuk penelitian ini 10 jenis ragam hias yang diproduksi pengrajin. Metode pengumpulan data yang digunakan adalah observasi dan dokumentasi. Hasil penelitian ini memperlihatkan hasil pengembangan ragam hias pada 10 sampel tembikar yang diproduksi pengrajin, peneliti membuat 10 desain ragam hias untuk mengembangkan ragam hias yang sebelumnya, sebagai hasil nyata pada penelitian ini maka dilakukan tindakan eksperimen oleh peneliti yang dibantu pengrajin dengan menerapkan langsung pada tembikar, peneliti memilih 2 dari 10 hasil pengembangan dan diaplikasikan langsung pada tembikar sebagai hasil dari penelitian ini.
\end{abstract}

Kata Kunci: Pengembangan, Ragam Hias, Tembikar

\begin{abstract}
This study aims to develop a variety of decoration in the business of pottery business from the indicators of the principles of fine art that are carried out in Sustainable Pottery ceramics crafts on Jalan Medan Tanjung Morawa, Deli Serdang Regency. This research uses a development method. Data collection methods used are observation and documentation. The results of this study show the results of the development of ornamental variations on 10 samples of pottery produced by craftsmen, the authors made 10 decorative designs to develop decorative designs before, as a tangible result in this study an experimental action was carried out by researchers assisted by craftsmen by applying directly to pottery, The researcher chose 2 out of 10 development results and applied them directly to the pottery as a result of this study.

Keywords: Development, Application of Ornamental,Pottery

How to Cite: Sinaga, S., Soeprayogi, H., \& Mesra. (2020). Eksperimen Pengembangan Ragam Hias Keramik Di Usaha Tembikar Lestari Deli Serdang. Journal of Education, Humaniora and Social Sciences (JEHSS). 3 (2): 586-593.
\end{abstract}




\section{PENDAHULUAN}

Seni kerajinan merupakan suatu bentuk karya manusia yang memiliki niali estetis dan nilai fungsional, seni keramik telah menjadi bagian dari aktivitas kebudayaan manusia dari zaman dahulu hingga hari ini.

Sesuai dengan kebutuhan manusia, keramik mengalami perkembangan dari abad ke abad secara evolusioner. Mulai dari bentuk, teknik pengolahan maupun teknik pembakaran. Dahulu pembuatan keramik masih menggunakan tangan manusia dan pembakaran dilakukan hanya dengan menggunakan daun-daun atau ranting-ranting tanpa diberi glasir dan hanya cukup dengan pembakaran rendah dan bentuknya masih sangat sederhana. Pada perkembangan selanjutnya berbagai faktor turut menentukan kemajuan keramik diberbagai daerah. Faktor-faktor tersebut antara lain, mulai dari faktor keperluan hidup, persediaan bahan baku sampai kemajuan teknik pembakaran. Dari faktor-faktor tersebut, faktor kebutuhan atau keperluan hidup merupakan pengaruh yang sangat dominan. Pada abad ke 3 atau 4 masehi keramik telah mengalami perubahan karena telah menggunakan unsur estetika dalam pembuatannya.

Di Indonesia kerajinan keramik juga sudah dikenal oleh masyarakat sejak zaman dahulu melalui hubungan dagang dengan orang-oang Tionghua di berbagai daerah yang menjadi pusat perdagangan. Pada masyarakat tradisonal kerajinan kermik ini masih dibuat atau diproduksi dengan teknik yang paling sederhana dengan teknik putar, dan menghasilkan produk keramik seperti gentong,gerabah,kendi,priuk dan sebagainya.

Perubahan dan perkembangan keramik bersumber dari faktor dalam dan faktor luar suatu komunitas. Dalam hal ini,kontribusi kaum intelektual tidak dapat dielakkan dalam membentuk system pengetahuan masyarakat, Pengembangan yang dilakukan lebih kepada peningkatan nilai tambah produk melalui aplikasi desain dan dekotasi produk keramik dengan ragam hias atau ornamen, memperkaya produk yang telah ada, dengan merujuk pada berbagai jenis produk dari bahan lain maupun bahan yang sama dari sumber berbeda. Replikasi yang dilakukan perngrajin keramik, semacam itu merupakan fenomena umum agar terhindar dari kesulitan ekonomis. Bentuk-bentuk keramik yang dikembangkan bisa meliputi: pralatan makan, minum,pot,vas bunga, peralatan rumah tangga, bahan keperluan bangunan eksterior dan interior, benda kerajinan dan benda seni yakni dengan memberi tekanan pada aspek dekorasi ornamen atau hiasan

Deli Serdang Khususnya di Kecamatan Tanjung Morawa Desa Bangun Sari sebagian masyarakatnya bermata pencaharian sebagai perajin keramik yang dirintis oleh Subur. Beliau adalah salah satu perajin keramik yang berasal dari kota Semarang, Jawa Tengah. Produk yang dihasilkan Subur pertama kali adalah gentong, Seiring dengan berkembangnya zaman produk yang dihasilkan di Tanjung Morawa semakin bervariasi. (Wawancara dengan: Irwansyah, Jumat, 19Juli 2019). Menurut hasil wawancara dengan pemilik Tembikar Lestari yang bernama Irwansyah menyatakan di Desa Bangun Sari pada Tahun 2014 terdapat 24 orang perajin gerabah. Namun, pada Tahun 2015 perajin di Desa Bangun Sari Kecamatan Tanjung Morawa ini hanya memiliki 15 perajin rumah produksi keramik, dikarenakan daya saing yang sudah begitu banyak. Tembikar Lestari salah satu yang dikelola Irwansyah sejak 17 juli 2004, yang masih bertahan karena pembuatan Keramik di Tembikar Lestari di mulai secara bertahap, seperti: badan keramik, kaki keramik, bibir keramik, dan motif. Industri kerajinan keramik Tembikar Lestari melibatkan tenaga kerja 5 orang perajin. Kapasitas produk di Tembikar Lestari mencapai 500 produk keramik setiap bulannya. Produk keramik yang dihasilkan berupa vas bunga dan guci hias yang ukurannya sangat bervariasi dan beragam (wawancara dengan bapak Irwansyah, Selasa 6 Agustus 2019). 
Beliau menyatakan bahwasannya teknik yang digunakan oleh Tembikar Lestari adalah teknik putar. Sedangkan dalam pemuatan keramik banyak teknik-teknik lain seperti: teknik slab, teknik pilin, teknik cetak, dan teknik pijit.

Seiring berjalannya waktu perkembangan produk keramik dalam segi bentuk keramik yang diproduksi pastinya sudah mengalami perubahan bentuk dari masa kemasa. Perubahan bentuk bisa saja dipengaruhi oleh pekembangan zaman. Karena tuntutan pasar, keindahan, serta kreatifitas mengalami perubahan di Desa Bangun Sari Tanjung Morawa dari Tahun ke Tahun. Namun desain yang dihasilkan pengrajin belum begitu bervariasi pola hiasnya, dari produk fungsional praktis menjadi objek estetis. Produk yang berorientasi kearah objek estetis dengan tingkat keberhasilan ekonomis agar mendorong konsentrasi pengrajin kejenis produk baru dan pembuatan produk-produk tradisionalyang selama ini diproduksinya semakin beragam, Jadi peneliti ingin mengembangkan desain keramik yang ada di Tembikar Lestari.

Seperti yang dijelaskan sebelumnya awal muncul industri keramik ini mulai merintis dari Tahun 2004, dan ekstitensinya masih terlihat sampai sekarang, namun kelemahan di Tembikar Lestari salah satunya terdapat pada desain tembikar dikarenakan Kreativitas pengrajin dalam mengolah desain desain yang dihasilkan dalam produksinya masih kurang, dan dinilai masih sederhana dalam memodifikasi dan belum berani mengkombinasikan dengan bahan lain pada pola hiasnya. Sehingga menghasilkan keramik yang memiliki desain biasa saja dan mengurangi ketertarikan konsumen. Berdasarkan latar belakang di atas, Maka penelitian ini berjudul : "Eksperimen Pengembangan Ragam Hias Keramik di Usaha Tembikar Lestari ditinjau dari PrinsipPrinsip Kerajinan "

Pengertian Eksperimen menurut Chourmain (2006) Metode penelitian eksperimen adalah penelitian yang memberikan manipulasi/perlakuan (treatment) terhadap variabel yang diteliti, sehingga dari dampak maupun efek penelitian itu orang dapat menciptakan data yang valid dan reliable guna menarik kesimpulan (inferensi) tentang hubunganhubungan kasual, korelasional dan dampak yang terjadi antara variabel - variabel tersebut.

Menurut Sukmadinata (2012) Penelitian eksperimental merupakan penelitian laboratorium, walaupun bisa juga dilakukan diluar laboratorium, tetapi pelaksanaannya menerapkan prinsip-prinsip penelitian laboratorium, terutama dalam pengontrolan terhadap hal-hal yang mempengaruhi jalannya eksperimen. Maka eksperimen kreatif tersebut berusaha membuktikan keberhasilan percobaan dalam hal membuat desain motif hias geometris melalui media baru berupa papan berpaku untuk menganalisis keberhasilan secara sistematis melalui pengamatan dari berbagai data yang diperoleh.

Pengertian pengembangan menurut Hornby Oxford Advanced Learners Dictionary (2019) menyatakan "The developments design is process of producing or creating sth new design or more advanced, a new or advanced product" "Pengembangan desain adalah proses memproduksi atau menciptakan desain baru atau lebih maju, produk baru atau lanjutan dari produk tersebut"

Kamus Besar Bahasa Indonesia, (2012), pengembangan adalah inovasi terhadap suatu media selalu dilakukan guna mendapatkan kualitas yang lebih baik. Maka disimpulkan Pengembangan merupakan proses yang dipakai untuk mengembangkan suatu produk untuk menyempurnakan produk yang ada bisa dipertanggung jawabkan (Rusdi et al., 2020; Utami et al., 2020).

Pengertian Ragan Hias menurut Soepratno (1997)“Ragam hias berasal dari bahasa Yunani yaitu dari kata "ornare" yang artinya hiasan atau perhiasan". Menurut Sulistyo 
(2005) " pola hias ini banyak untuk menghiasi alat-alat yang dihasilkan orang untuk membuat hiasan pada alat-alat tersebut, di samping mendatangkan nilai keindahan juga berhubungan dengan unsur religi (kepercayaan). Maka peneliti dapat menyimpulkan bahwa ragam hias adalah hiasan yang dibuat untuk meningkatkan kualitas atau nilai dari suatu benda atau produk.

Pengertian Keramik McLaren dalam Encyclopedia Americana(1996) disebutkan keramik adalah suatu istilah yang sejak semula diterapkan pada karya yang terbuat dari tanah liat alami dan telah melalui perlakukan pemanasan pada suhu tinggi. Menurut Susanto (2018) Keramik adalah karya seni yang dibuat dengan bahan tanah liat, dapat berupa benda dua dimensi maupun tiga dimensi. Istilah ini sering mengarah pada karya yang dibuat dengan tangan,baik berupa benda fungsional maupun sebagai karya seni, tembikar, terakota dan raku.

Salza (2016) Keramik merupakan benda yang terbuat dari tanah liat melalui proses pembakaran. Pembakaran tanah liat dengan suhu tinggi menghasilkan keramik porselin (keramik halus), dan bakaran suhu rendah menghasilkan gerabah (terakota).Berdasarkan pendapat di atas dapat disimpulakan bahwa keramik adalah produk yang dibuat dari bahan tanah liat yang dibakar dengan temperatur suhu tertentu. Berdasarkan pendapat di atas dapat disimpulakan bahwa keramik adalah produk yang dibuat dari bahan tanah liat yang dibakar dengan temperatur suhu tertentu.

\section{METODE PENELITIAN}

Penelitian bersifat pengembangan ini merupakan suatu pengembangan gaya penciptaan yang baru agar terlihat lebih unik dan berkreasi serta berkarakter, yang bertujuan untuk menghasilkan sesuatu yang baru dan telah mengalami perubahan yang lebih inovatif dan efektif.

Selama proses penelitian berlangsung ada beberapa tahapan yang penulis lakukan.

1. Pengamatan, Dalam proses menciptakan gambar ragam hias yang kita inginkan, pengamatan perlu dilakukan dalam mengenali bentuk dan karakter dari hiasan yang hendak dibuat. Pengamatan ini dilakukan secara berulang-ulang agar gambaran desain yang hendak dibuat dapat ditentukan.

2. Pemilihan Bentuk Hiasan, setelah melakukan pengamatan terhadap bentuk dan karakter yang disukai, rancanglah beberapa hiasan yang akan di padukan yang tentunya dapat dipadukan Sehingga desain yang hendak dibuat lebih terkonsep dan dapat disimpulkan arti dari konsep desain yang dibuat.

3. Menentukan Konsep Desain, setelah memilih hiasan yang hendak dibuat, mulailah membuat konsep desain seperti bentuk posisi dan peletakan hiasan yang hendak dibuat di sebuah kertas. Setelah terkonsep dengan baik desain bentuk baru yang hendak dibuat pindahkanlah konsep tersebut ke atas kertas A3 dan buatlah desain aslinya.

4. Penyelesaian Akhir (finishing). setelah desain sudah siap, kemudian mulailah proses mewarnai sesuai dengan imajinasi dan keinginan. Kemudian setelah selesai proses mewarnai, perhatikanlah secara keseluruhan apakah sudah sempurna dan sesuai dengan konsep? Jika sudah, maka anda sudah menyelesaikan karya tersebut dengan baik. 


\section{HASIL DAN PEMBAHASAN \\ Pengembangan Ragam hias pada Tembikar hasil produksi Tembikar Lestari dengan Desain Ragam hias baru.}

\section{Guci I}
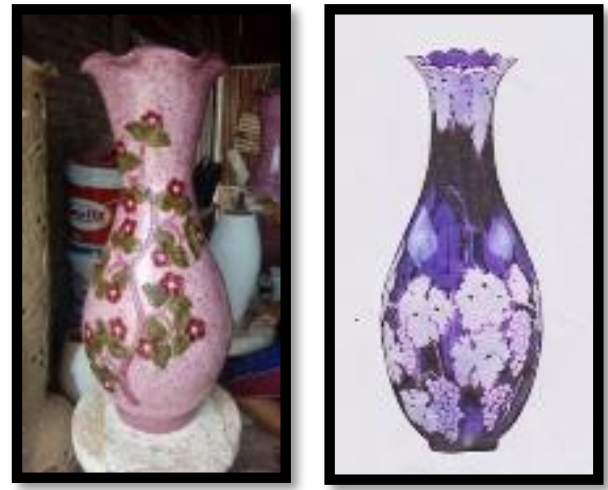

Gambar 1 Hasil pengembangan produk tembikar I (Foto: Sartika Sinaga 2020)

Pada indikator bentuk, keramik ini berbentuk silindris menyerupai bentuk vas bunga seperti pada umumnya dan memiliki tinggi $60 \mathrm{~cm}$. Untuk indikator keamanan, tentu sangat aman karena tidak memiliki permukaan tajam sehingga aman bagi penggunanya. Kemudian indikator fungsi, sebagai fungsi hias mengingat ragam hias pada keramik ini memiki nilai estetik yang baik dan juga dapat digunakan sebagai vas bunga. Untuk indikator Keindahan ragam hias, memiliki bentuk ragam hias buah anggur dan daunnya yang mengelilingi bagian badan dan kepala guci tata letak antara motif satu dengan yang lainnya memiliki komposisi yang baik, antara warna dan bentuk ragam hiasnya serasi, dan penempatan ragam hias yang satu dengan yang lainnya berkesinambungan. jarak antara motif ragam hias satu dengan yang lain sama dan bentuk motif mengalami pengulangan yang signifikan. bentuk objek/ jenis motif yang jelas, terdapat warna yang kontras diantara ragam hias, penulis sengaja membuat motif bayangan di antara motif" yang terlihat jelas agar guci terlihat transparan, ukuran ragam hias tidak terlalu besar dan tidak teralalu kecil semua, variasi warna yang tercipta antara motif menarik dengan gradasi warna ungu muda dan tua mengelilingi setiap bagian motifnya, pengulangan bentuk ragam hias yang bervariasi serta ukuran yang beragam. Pada Indikator Teknik yang digunakan untuk membuat ragam hias keramik ini adalah teknik lukis. Dan indikator ukuran memiliki ukuran tinggi $60 \mathrm{~cm}$.

\section{Guci II}

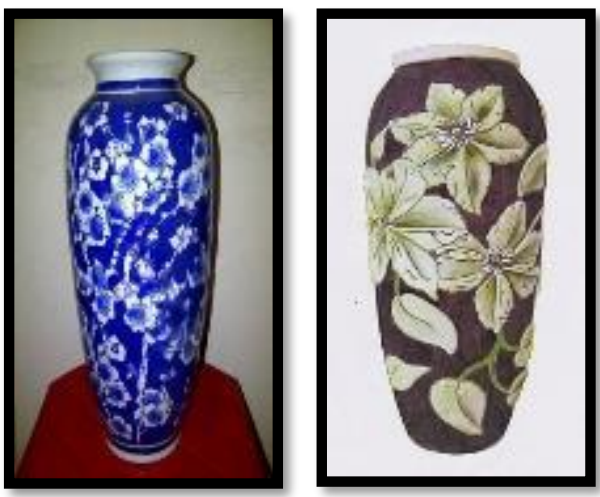

Gambar 2 Hasil pengembangan produk tembikar II (Foto: Sartika Sinaga)

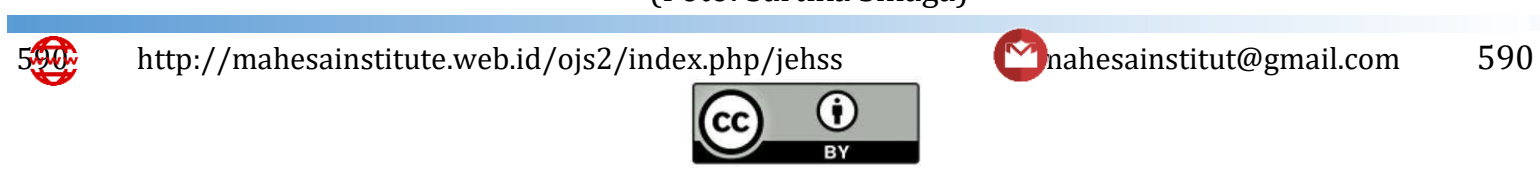

This work is licensed under a Creative Commons Attribution 4.0 
Pada indikator bentuk, keramik ini berbentuk silindris seperti gentong air memiliki tinggi 60 $\mathrm{cm}$. Untuk indikator keamanan, tentu sangat aman karena tidak memiliki permukaan tajam sehingga aman bagi penggunanya. Kemudian indikator fungsi, sebagai fungsi hias mengingat ragam hias pada keramik ini memiki nilai estetik yang baik dan juga dapat digunakan sebagai vas bunga juga sebagai alat penyimpan barang tertentu. Untuk indikator Keindahan ragam hias, memiliki bentuk ragam hias tumbuhan berupa bunga dan daunnya yang mengelilingi seluruh bagian badan guci, tata letak antara motif satu dengan yang lainnya memiliki komposisi yang baik, antara warna dan bentuk ragam hiasnya serasi, dan penempatan ragam hias yang satu dengan yang lainnya berkesinambungan. jarak antara motif ragam hias satu dengan yang lain sama dan bentuk motif mengalami pengulangan yang signifikan. bentuk objek/ jenis motif yang jelas, terdapat warna yang kontras diantara ragam hias, ukuran ragam hias cukup dan terlihat sangat jelas dibagian badan guci, variasi warna yang tercipta antara motif menarik dengan gradasi warna hijau muda dan tua mengelilingi setiap bagian ragam hiasnya, pengulangan bentuk ragam hias dengan ukuran yang sama. Pada Indikator Teknik yang digunakan untuk membuat ragam hias keramik ini adalah teknik pilin dan lukis. Dan indikator ukuran memiliki ukuran tinggi $90 \mathrm{~cm}$.

\section{Guci III}

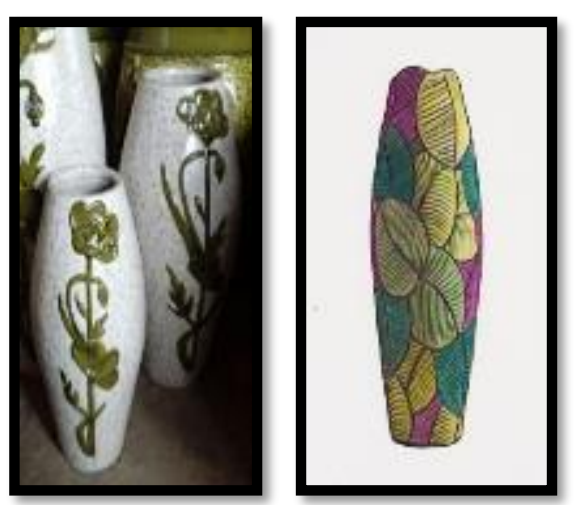

Gambar 3 Hasil pengembangan produk tembikar III

(Foto: Sartika Sinaga)

Pada indikator bentuk, keramik ini berbentuk silindris seperti pipa air yang dibagian atas dan bawahnya mengecil dan memiliki tinggi 1 meter. Untuk indikator keamanan, tentu sangat aman karena tidak memiliki permukaan tajam sehingga aman bagi penggunanya. Kemudian indikator fungsi, sebagai fungsi hias mengingat ragam hias pada keramik ini memiki nilai estetik yang baik. Untuk indikator Keindahan ragam hias, memiliki bentuk ragam hias tumbuhan berupa dedaunan yang terdapat seluruh bagian guci, tata letak antara motif satu dengan yang lainnya memiliki komposisi yang baik, antara warna dan bentuk ragam hiasnya serasi, dan penempatan ragam hias yang satu dengan yang lainnya berkesinambungan. jarak antara motif ragam hias satu dengan yang lain sangat rapat dan bentuk motif mengalami pengulangan yang signifikan. bentuk objek/ jenis motif yang jelas, terdapat warna yang kontras diantara ragam hias, ukuran ragam hias tidak cukup besar, variasi warna yang tercipta antara motif menarik dengan gradasi warna kuning hingga hijau tua dan tambahan warna ungu dibeberapa bagian ragam hias, pengulangan bentuk ragam hias yang bervariasi serta ukuran yang sama. Pada Indikator Teknik yang digunakan untuk membuat ragam hias keramik ini adalah teknik lukis. Dan indikator ukuran memiliki ukuran tinggi 1 meter. 
Sartika Sinaga, Heri Soeprayogi \& Mesra, Eksperimen Pengembangan Ragam Hias Keramik Di Usaha Tembikar Lestari Deli Serdang

\section{Hasil Eksperimen}
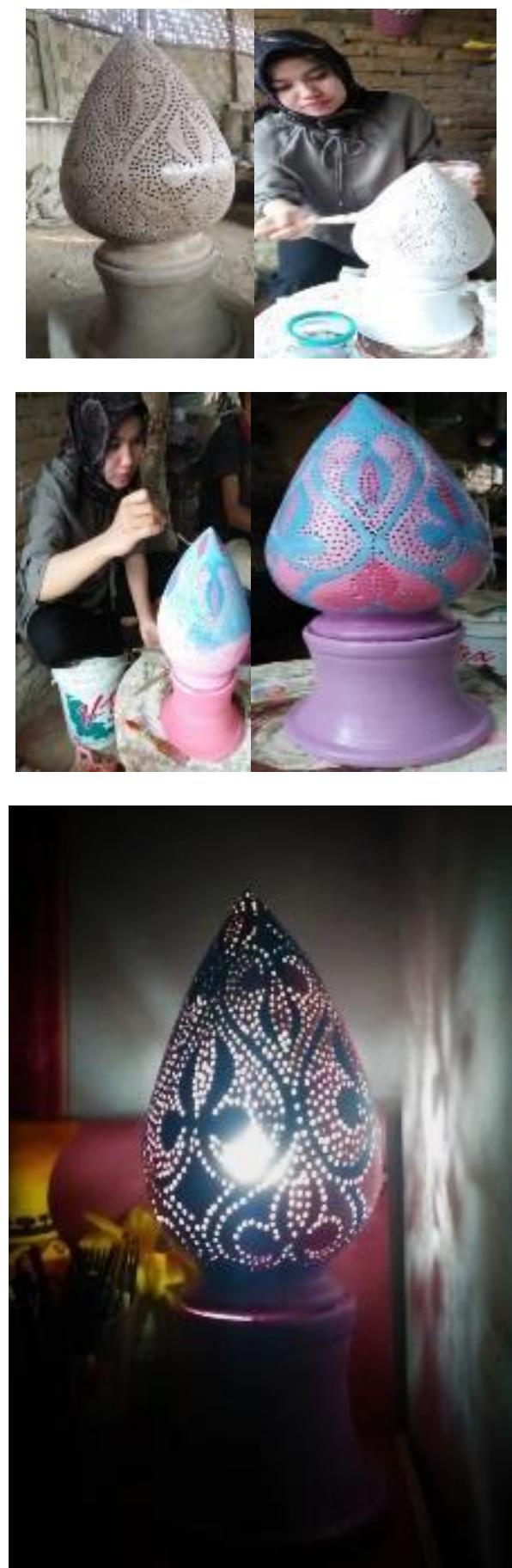

Gambar 4 Hasil Eksperimen

(Foto: Sartika Sinaga)

\section{SIMPULAN}

Pengembangan ragam hias pada Tembikar Lestari belum terlihat banyak perubahan yang terjadi dari tahun ketahun, mengingat kurangnya kekreatifitasan pengrajin dalam

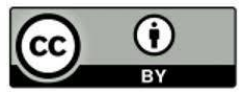


mendesain motif motif untuk di gunakan pada produknya, sehingga bentuk dan pola hiasnya masih mengikuti desain turun menurun dan tidak menutup kemungkinan mempengaruhi nilai jual produk tersebut. Ragam Hias yang diterapkan pada Tembikar Lestari seperti motif flora, ornamen Melayu, dan Batak Toba. Ada juga beberapa ragam hias yang dibuat dari kulit telur yang membentuk mozaik yang menempel diseluruh badan tembikar. Dari Hasil pengembangan ragam hias yang telah dilakukan peneliti memiliki pada keramik akan menjadi refrensi bagi pengrajin untuk mendesain ragam hias pada produknya.

\section{DAFTAR PUSTAKA}

Chourmain, (2013). Metode penelitian Jakarta Barat : Penerbit Moeka Publishing

Encyclopedia Americana, (1996 )., http://www.aliexpres.com diakses pada 24 Oktober 2015/13.00

Hornby, AS. (2019). Oxford Advanced Learner's Dictionary Of Current Englist. London: Penerbit Oxford University Press

KBBI. (2012). Kamus Besar Bahasa Indonesia. Jakarta: BalaiPustaka

Mc Laren. The Concise Colombia Encyclopediahttp://studiokeramik.org/diaksespada tanggal 26 Oktober 2015/09.10

Rusdi, L., Soeprayogi, H., \& Mesra, M. (2020). Kerajinan Anyaman Bambu Di Sanggar Kreatif "Bunga Matahari" Kelurahan Rambung Barat Kecamatan Binjai Selatan. Journal of Education, Humaniora and Social Sciences (JEHSS), 3(1), 133-140. doi:https://doi.org/10.34007/jehss.v3i1.216

Soepratno, (1997).Mengenal Budaya Bangsa Indonesia Ornamen Ukir Kayu

Sukmadinata,Nana. S. (2012). Metode dan Penelitian.Bandung: PT RemajaRosdakarya Offset

Sulistyo,H \&Edi Tri. (2005), Kaji dini, Pendidikan Seni, Surakarta: Lembaga Pengembangan Pendidikan (LPP) UNS dan UNS Press

Susanto, M. (2018). Diksi Rupa. Yogyakarta: Penerbit Dictiart Laboratory

Utami, A., Soeprayogi, H., \& Azis, A. (2020). Pembuatan Kerajinan Bunga Berbahan Kulit Jagung Ditinjau dari Prinsip-prinsip Seni Rupa dan Kerajinan. Journal of Education, Humaniora and Social Sciences (JEHSS), 3(1), 260-264. doi:https://doi.org/10.34007/jehss.v3i1.282

Widagdo. (2000). Desain dan Kebudayaan. Bandung: Direktorat Jenderal Pendidikan Tinggi 